\title{
Region: Lazio; Province: Rome; Site: Tivoli
}

\section{Maria Elena Gorrini}

Dipartimento Studi Umanistici, Università degli Studi di Pavia

mariaelena.gorrini@unipv.it

\section{Milena Melfi}

Faculty. of Classics and Ashmolean Museum, University of Oxford

milena.melfi@classics.ox.ac.uk

\section{Tivoli, Hadrian's villa: the Plutonium project}

In the Spring and Summer of 2016 and 2017, the Universities of Oxford and Pavia, led by Milena Melfi and Maria Elena Gorrini, in collaboration with the British School at Rome and the Geophysic Lab of the University of Camerino, carried out non-invasive investigations of the area of Hadrian's Villa traditionally interpreted, from the $16^{\text {th }}$ century onwards, as a reproduction of the Underworld. The little-studied and never published site (for a discussion of the previous research in the area cf. Gorrini-Melfi-Montali-Schettino in press, with full bibliography), is located on one of the highest rises of the complex, in the East part of the Villa (fig.1) and it consists of: i) the Inferi, a Grotto/cave/nymphaeum connected to an artificial canal wherewater was channeled to evoke the river Styx in the land of the dead; ii) The Plutonium or Temple of Pluto/Hades, Lord of the Underworld, known from the first travelers' accounts as a large building on a high podium; iii) a network of underground passages, partially connecting to the known routes running under the villa.

\section{Fig. 1. The Plutonium complex}

Archaeology graduates from both universities took part in this 2018 first season of excavations and contributed in bringing to light part of an extraordinary circular or semicircular structure, projecting from the $\mathrm{E}$ wall of the Plutonium, previously recorded by the GPR surveys conducted by the BSR first and the University of Camerino later (fig. 2).

\section{Fig. 2. The geomagnetic survey (Ghezzi et alii in press)}

This consists of a low wall, of ca. $36 \mathrm{~m}$ diameter, pierced by substantial lead water pipes (30 $\mathrm{cm}$ diam) possibly supplying water under pressure into a the circular or semi-circular structure (fig.3). The fact that all walls seem to have been entirely covered in blue plaster and the remains of the floor have produced a large number of blue mosaic tesserae suggests that the structure was related to the collection of water. Another trench opened SW of the Plutonium, where the GPR survey had revealed an intersection of the curved wall with a pair of parallel walls perpendicular to the building - though inconclusive at present-similarly suggests the exploitation of water, for the presence of structures and decoration normally associated with thermal establishments.

\section{Fig. 3. Plan of the Plutonium with trench A}

Inside the Plutonium, the rooms surrounding the central courtyard were also cleaned and surveyed (fig. 3). The results pointed at a very open building, with large windows and balconies, providing vistas on the surrounding landscape and exploiting its elevated position. 
Except from its NW side, where a structure on high podium, with a temple-like façade seems to have been located, the building appears like a large garden pavilion, surrounded by columns in the Ionic order, the monumental entrance of which, was embellished with our circular or semi-circular water feature (the extent and function of which will be investigated next year). The building was probably part of an artificially landscaped area, not only because of the proximity with the manmade valley of the Inferi. The computer generated magnetization model elaborated by Annalisa Ghezzi (Ghezzi et alii, in press, fig. 2), following the most recent geomagnetic surveys, reported a pattern of ditches dug in the tufa bed between Inferi and Plutonium to be interpreted as a system of irrigation ducts and planting pits. This indicates the presence of a garden that finds comparisons in other parts of the villa, and can explain the numerous finds of ollae perforatae, typical clay vessels with perforations at the bottom and sides for planting, in the course of the excavations.

\section{Acknowledgements:}

The Plutonium Project is jointly directed by Maria Elena Gorrini and Milena Melfi, working in close collaboration with Villa Adriana - Villa d'Este (dr. Andrea Bruciati, dr. Benedetta Adembri and dr. Sabrina Pietrobono). The project greatly benefits from the support of architect Gilberto Montali, Università di Palermo, Francesco Ferruti, Società Tiburtina, and the team of geophysics led by Prof. Antonio Schettino, Università di Camerino. The research team consists of of many students, all here gratefully acknowledged for their dedicated work: Nadia Aleotti, Isabella Bossolino, Massimiliano Di Fazio, Elisabetta Di Virgilio, Paula Gaither, Rodney Mackenzie, Benedetta Peverelli, Lorenzo Radaelli, Giuseppe Restaino, Thomas Runeckles, Mirjam Von Bechtolsheim.

\section{References:}

Ghezzi et alii in press: Ghezzi, A.; Schettino, A.; Pierantoni, P.P.; Conyers, L.; Tassi, L.; Vigliotti, L.; Schettino, E.; Melfi, M.; Gorrini, M.E.; Boila, P., Reconstruction of a Segment of the UNESCO World Heritage Hadrian's Villa Tunnel Network by Integrated GPR, Magnetic-Paleomagnetic, and Electric Resistivity Prospections. Preprints 2019, 2019050193 (doi: 10.20944/preprints201905.0193.v1)

Gorrini, M.E.; Melfi, M.; Montali, G.; Schettino, A., Il progetto Plutonium di Villa Adriana: Prime considerazioni a margine del nuovo rilievo e prospettive di ricerca. In G.E. Cinque et al. eds., Adventus Hadriani, Convegno internazionale di studi, Roma-Tivoli 4-7 luglio 2018, in press. 